\title{
MENINJAU KEMBALI TEORISASI MENGENAI DESENTRALISASI, COMMUNITY DRIVEN DEVELOPMENT, DAN KAPITALISASI AGRARIA
}

\author{
Re-reviewing the Theorization of Decentralization, Community Driven \\ Development, and Agrarian Capitalization
}

\author{
Noer Fauzi Rachman \\ Guru dan Peneliti Studi Agraria Indonesia, memperoleh PhD dalam Environmental \\ Science, Policy and Management (ESPM) - University of California Berkeley. \\ Email: noerfauziberkeley@gmail.com
}

\begin{abstract}
Thearticleshowsa theoretical debateon the consequence of decentralization policyand Community Driven Development (CDD) especially in relation to the way capitalism develop. The decentralization policy reshapes local government bureaucracy more responsive and accountable toward people's needs, and the CDD facilitate rural and urban communities to manage collectively efforts to eradicating their poverty condition. Both are promoted by neo-institutionalist thinking in the World Bank and Civil Society within the same interlocking direction. Furthermore, I explicate critiques toward theory and practice of decentralization policy and CDD, launched by Vedi Hadiz, Toby Carroll, Tania Li, and Frederich Rawski. I connect those with the theorization of the ways capitalism develop as articulated by Paul Cammack, Michael Perelman, Massimo de Angelis and David Harvey. I argue that the presence of space of struggle, contestation and negotiation open the possibility for multiple forces to participate, or refuse to participate, to reshape the practice of decentralization and CDD, and furthermore the forces dialectically are reshaped because of their struggle, contestation and negotiation.
\end{abstract}

Keywords: Decentralization, Community Driven Development (CDD), capitalism, space of contestation and negotiation, social movement.

Intisari: Artikel ini mengemukakan debat teori dari konsekuensi kebijakan desentralasi dan Pembangunan Berbasis Masyarakat (CDD) terutama dalam hubungannya dengan bagaimana kapitalisme berkembang. Kebijakan desentralisasi telah membentuk pemerintah lokal menjadi lebih responsif dan akuntabel terhadap kebutuhan masyarakat, dan CDD telah memfasilitasi komunitas perkotaan maupun perdesaan untuk secara kolektif berusaha mengatasi kondisi kemiskinannya. Selanjutnya, penulis mengutarakan kritik terhadap teori dan praktik kebijakan desentralisasi dan CDD, yang dikemukakan oleh Vedi Hadiz, Toby Carroll, Tania Li dan Frederich Rawski. Penulis juga menghubungkan teori tersebut dengan teorisasi tentang bagaimana kapitalisme berkembang seperti yang dikemukakan oleh Paul Cammack, Michael Perelman, Massimo de Angelis dan David Harvey. Penulis berpendapat bahwa keberadaan ruang pertarungan, kontestasi dan negosiasi membuka kemungkinan untuk berbagai kekuatan untuk berpartisipasi, atau menolak untuk berpartisipasi, untuk membentuk kembali praktik desentralisasi dan CDD, dan selanjutnya kekuatan dialektika dibentuk kembali karena usaha, kontestasi dan negosiasi mereka.

Kata Kunci: Desentralisasi, Community Driven Development (CDD), kapitalisme, ruang-ruang pertarungan dan perundingan, gerakan sosia. 


\begin{abstract}
"Tujuan teorisasi bukan untuk meningkatkan reputasi intelektual atau akademis seseorang, melainkan untuk membuat kita mampu menangkap, memahami dan menjelaskan, singkatnya untuk mendapatkan pengetahuan yang memadai mengenai dunia yang menyejarah serta proses-prosesnya sedemikian rupa sehingga memberikan kita informasi cara bagaimana mentransformasikannya”.
\end{abstract}

(Stuart Hall 1988: 36)

\section{A. Pendahuluan}

Kebijakan otonomi daerah di Indonesia yang mulai diberlakukan pada tahun 2001 dengan cepat mengubah Indonesia dari negara unitaris dengan sistem paling sentralis menjadi negara dengan sistem paling desentralistis di dunia. Dua ahli dari Bank Dunia Hofman dan Kaissermengkalimdemikian, danmenyebutnya sebagai Big Bang Desentralisation karena karakteristik-karakteristik berikut:

a. Perundang-undangan baru tentang desentralisasi menyediakan otonomi luas untuk seluruh gugus tugas kecuali beberapa gugus tugasyang secara tegas ditetapkan oleh pusat - termasuk pertahanan, pengadilan, kepolisian dan perencanaan pembangunan.

b. Pada tahun 2002 andil pengeluaran pemerintah daerah naik 40 persen, meningkat tajam dibanding rata-rata 15 persen di tahun 90-an

c. Selain pengeluaran, banyak aparatus pemerintah berada dibawah kendali daerah-daerah. Lebih dari 2,1 pegawai negeri sipil atau hampir 2/3 tenaga kerja pemerintahan pusat dialihkan ke daerahdaerah. Kini sekitar 2,8 juta dari 3,9 juta pegawai negeri sipil dikategorikan sebagai pegawai negeri sipil daerah. d. Terdapat 239 kantor-kantor perwakilan pemerintah pusat tingkat provinsi, 3.933 kantor-kantor tingkat lokal, lebih dari 16.000 fasilitas pelayanan seperti sekolah, rumah sakit, pusat pelayanan kesehatan, yang sepenuhnya dialihkan ke pemerintahan daerah di seluruh Indonesia (Hofman dan Kaiser 2002: 1).

Naskah ini tidak akan menelusuri asal usul kebijakan desentralisasi itu, menelusuri perubahan kebijakan-kebijakan yang terusmenerus terjadi, ataupun mengevaluasi keberhasilan atau kegagalan implementasinya. Akan tetapi, saya akan mengkaji ulang dengan menyajikan secara padat beberapa perdebatan teoritik seputar arah dan konsekuensi dari desentralisasi tersebut dikaitkan dengan Community Driven Development (CDD), yang juga sejak awal diprogramkan oleh Bank Dunia. Saya menempatkan kedua jenis proyek Pembangunan (development projects) itu dalam hubungan dengan pembangunan kapitalis (capitalist development) yang formasi sosial dan sejarahnya berbeda-beda antara satu lokasi dengan lokasi lainnya.

CDD dapat disebut Big Bang juga yang melanjutkan berbagai bentuk Social Fund, yang dimulai dalam bentuk kucuran dana-dana Jaring Pengaman Sosial (JPS), social safety net, untuk menanggulangi ketidakmampuan daya beli masyarakat miskin dan mencegahnya berpartisipasi dalam kerusuhan (Bank Dunia 2001). Para antropolog dalam Bank Dunia di Indonesia kemudian mengembangkan social fund ini sedemikian rupa sehingga menjadi apa yang dikenal dalam kosa kata Bank Dunia sekarang ini dengan nama Community Driven Development (CDD). Dua proyek CDD terbesar adalah Program Pengembangan Kecamatan (PPK) dan Program Penanggulangan Kemiskinan Perkotaan ( $\left.\mathrm{P}_{2} \mathrm{KP}\right)$. Menurut perhitungan staf Bank Dunia, seluruh 
pinjaman Bank Dunia untuk proyek tersebut telah melonjak dari 325 juta dolar AS di tahun 1996 menjadi 2 milyar dolar di tahun 2003 atau jika turut disertakan dengan pinjaman untuk menyiapkan kondisi yang layak bagi keberlangsungan proyek tersebut pinjaman itu mencapai 3 Miliar dollar di tahun 1996, meningkat menjadi 7 Milyar dollar di tahun 2003 (Mansuri and Rao 2004:2). Saat itu, proyek-proyek CDD di Indonesia merupakan sebuah pinjaman pembangunan Bank Dunia yang paling besar, paling penting dan paling utama.

Di Indonesia, proyek CDD yang terbesar adalah Program Pengembangan Kecamatan (PPK). Cakupan wilayah PPK membengkak, meluas dari sebuah pelaksanaan percontohan kecil di 25 desa pada tahun 1997; kemudian tahun 2003 menjadi lebih dari 28.ooo desa (Guggenheim, Wiranto, Prasta, and Wong 2004). Program ini terutama menyediakan mekanisme jalan baru bagi masyarakat untuk dapat mengakses dana pembangunan secara langsung. Tidak seperti proyek-proyek Bank Dunia sebelumnya yang menempatkan pemerintah Indonesia sebagai pemilik proyek dan rakyat didudukkan sebagai penerima manfaat, dalam CDD kelompokkelompok masyarakatlah yang memiliki proyek itu. Dengan bantuan fasilitator, satu kelompok masyarakat memprakarsai, merencanakan proyek dan menyampaikannya pada forum antar desa di kecamatan. Pada setiap forum terjadi diskusi tentang alasan pentingnya, pengelolaannya, dan kapasitas menjalankannya. Juga ada penilaian keuangan dan ahli teknik lokal (antara lain seorang insinyur di kabupaten) yang kemudian akan membuat daftar urutan proyek-proyek yang akan didanai. Karena jumlah alokasi uang bagi setiap kecamatan relatif tetap, maka terbentuklah kompetisi antar proposal. Bagi yang mendapatkan proyek, kelompok itu membuat rekening bank sendiri dan dapat menarik uang secara langsung dari sebuah bank. Mereka akan menerima uang proyek kirakira paling lambat tiga bulan setelah perjanjian kontrak ditandatangani di forum perencanaan pembangunan di tingkat kecamatan.

Di tahun 2007, pemerintah Indonesia telah meningkatkan skala proyek-proyek CDD ini menjadi suatu program nasional bernama Program Nasional Pemberdayaan Masyarakat Mandiri (PNPM Mandiri), sebagai andalan untuk pengentasan kemiskinan, dengan jangkauan 2.827 kecamatan dengan alokasi anggaran sekitar Rp. 3,6 trilyun. Pada tahun 2008, jumlah kecamatan yang dijangkau ditargetkan akan menjadi 3.999 kecamatan dengan anggaran yang disediakan sekitar 13 trilyun. Sedangkan pada tahun 2009 diagendakan seluruh kecamatan di Indonesia yang berjumlah sekitar 5.263 kecamatan akan mendapat PNPM Mandiri. Besarnya bantuan langsung jika pada tahun 2007 antara Rp 750 juta s/d Rp 1,5 milyar per kecamatan, maka pada tahun 2008 besarnya bantuan per kecamatan sudah ada yang mencapai Rp 3 milyar (Menko Kesra 2008). Hingga akhir masa kepemimpinan SBY-Boediono pada 2014, secara total Program Pengembangan Kecamatan dan bentuk barunya, yakni PNPM Mandiri Perdesaan, telah mengalokasikan dana Bantuan Langsung Masyarakat (BLM) sebesar Rp 74,46 triliun. Sedangkan dana Bantuan langsung Masyarakat (BLM) dari Proyek Penanggulangan Kemiskinan Perkotaan (P2KP) dan bentuk barunya bernama PNPM Mandiri Perkotaan tahun 2008-2013 sebesar Rp 9,124 triliun dan pada 2014 dana yang dialokasikan sebesar Rp 1,38o triliun.

Oleh perancangnya, proyek-proyek CDD ini diklaim telah berhasil menataulang kepemerintahan lokal Indonesia. Demikian pula pemerintah Indonesia secara resmi mengklaim bahwa PNPM Mandiri dan 
pendahulunya "telah menghasilkan berbagai dampak positif terhadap peningkatan kapasitas, kesejahteraan, dan kemandirian masyarakat" (Tim PNPM 2014). Pada tahun 2004, berdasarkan implementasi dan hasilhasil proyek, program-program CDD mampu meningkatkan kualitas kerangka kerja desentralisasi dengan cara:

a. Lebih mendorong partisipasi warga negara, suara, dan akuntabilitas pemerintahan lokal;

b. Menyediakan cara yang efektif untuk menyampaikan pelayanan-pelayanan yang amat dibutuhkan dalam konteks desentralisasi dengan biaya yang lebih efektif dan waktu yang lebih efisien; serta

c. Secara langsung menginformasikan dan membentuk aturan-aturan desentralisasi (Wong dan Guggenheim 2005:254).

Telah jelas adanya agenda yang eksplisit dari kebijakan desentralisasi Indonesia yang berorientasi pada transformasi dari birokrasi pemerintah yang sentralistik, birokratis, otoriter, pemburu rentedan juga represif beralih menjadi pemerintah yang lebih responsif dan bertanggungjawab. Telah jelas pula agenda proyek-proyek CDD yang menempa komunitas-komunitas pedesaan dan perkotaan mengembangkan prinsip-prinsip 'mengatur diri sendiri'. Keduanya, birokrasi pemerintahan daerah dan komunitas-komunitas itu, terus dipermak menjadi agen-agen aktif penyokong apa yang dikenal dengan istilah "tata pemerintahan yang baik" (good governance). Seperti nanti akan ditunjukkan dalam artikel ini, keduanya merupakan neoliberal subject yang dibutuhkan bagi pembangunan kapitalis yang lebih luas. Artikel ini bermuara pada suatu kesimpulan tentatif mengenai tersedianya berbagai arena pertarungan dan perundingan (spaces of contestation and negotiation) baru dimana berbagai kekuatan sosial-- baik yang berasal dari kekuatan dari pihak masyarakat politik, pengusaha kapitalistik, organisasi masyarakat sipil maupun gerakan sosial--dapat aktif terlibat, atau juga dapat menolak, atau tidak memiliki kapasitas untuk terlibat, membentuk, mengisi ruang-ruang itu, serta untuk selanjutnya secara dialektis dibentuk kembali oleh arah, dinamika dan hasil pertarungan dan perundingan beragam kekuatan-kekuatan tersebut.

Penulis berusaha meninjau kembali debat teoritik mengenai tersedianya ruangruang pertarungan dan perundingan baru dan berbagai kekuatan sosial yang bekerja di dalamnya, dengan meletakkannya dalam konteks pembangunan kapitalisme. Dalam hal ini penulis mengerjakan kembali alat kerja analitik yang dikembangkan oleh Gillian Hart (2002), khususnya mengenai pembedaan antara Pembangunan (dengan huruf "P" besar) sebagai "suatu proyek intervensi paskaperang dunia kedua terhadap negara-negara 'dunia ketiga' yang berkembang dalam konteks dekolonisasi dan perang dingin (cold war)", dan pembangunan (dengan "p" kecil) yang "merupakan pembangunan kapitalisme sebagai suatu rangkai-proses sejarah yang dipenuhi dengan beragam kontradiksidansecarageografis tidak sama antara satu lokasi dengan lokasi lainnya" (Hart 2001: 650). Dengan demikian, saya menempatkan kebijakan desentralisasi dan proyek-proyek CDD bukanlah khas Indonesia, melainkan suatu bentuk kontemporer dari Pembangunan saat ini.

\section{B. Argumen Bank Dunia}

Dimulai sejak awal abad 21, Bank Dunia telah banyak sekali mengubah pendekatan pembangunan dari Structural Adjustment (Penyesuaian Struktural) menjadi Comprehensive Development Framework (Kerangka Pembangunan Komprehensif). Meski diluncurkan di tahun 1999, CDF 
bukanlah hal baru. Yang baru adalah kombinasi seluruh komponen-komponen menjadi sebuah kerangka untuk mengarahkan bantuan pembangunan, yakni:

a) Hambatan-hambatan pembangunan itu bersifat sosial dan struktural, yang tidak bisa hanya diatasi sematamata melalui stabilitas ekonomi dan kebijakan penyesuaian kebijakan belaka. Pembangunan membutuhkan visi kebutuhan dan solusi yang holistik dan berjangka panjang.

b) Reformasi kebijakan dan pelembagaan pembangunan tidak bisa diimport atau dipaksakan; tanpa kepemilikan domestik, reformasi dan investasi tidak akan bertahan lama.

c) Keberhasilan pembangunan mensyaratkan kemitraan antara pemerintah, masyarakat lokal, sektor swasta, masyarakat sipil serta pelaku-pelaku pembangunan lainnya; dan

d) Aktivitas-aktivitas pembangunan harus diarahkan dan dinilai berdasarkan hasil yang telah dicapai sebelumnya.

Perubahan ini dipahami dapat sebagai respon Bank Dunia terhadap pengalaman negatif kegagalan resep kebijakan mereka, terlihat nyata setelah krisis keuangan Asia-Timur (Pender 2001). Juga sebagai suatu konsekuensi dari "paradigma baru pembangunan" yang meletakan "pembangunan sosial" sepenting "pembangunan ekonomi” (Stiglitz 2002). Akan tetapi, mengapa perubahan ini terjadi tepat saat hadirnya demokrasi liberal pasca kejatuhan rejim otoriter-sentralis, seiring dengan semakin meluasnya kemiskinan, semakin terkonsentrasinya kekayaan pada perusahaan transnasional, menjamur dan besarnya peran LSM dalam pembangunan lokal, dan saat gerakan protes mendunia menentang institusi dan juga kebijakan neoliberal? Untuk mendapat jawaban yang lebih memuaskan kita bisa merujuk pada karya-karya Michael Goldman (2005a, 2005b), Penny Griffin (2006), David Craigh dan Doug Porter (2006) yang memberi penjelasan penting tentang cara bagaimana Bank Dunia menjalani rute-rute tertentu, menggunakan dan mengubah paradigma pembangunannya dari waktu ke waktu hingga pada giliriannya sampai pada yang disebut sebagai PostWashington Consensus. ${ }^{1}$

Sekelompok ekonom makro di Bank Dunia mengerangkakan desentralisasi dalam konteks Comprehensive Development Framework itu dengan menggunakan teori Rational Choice, dan memperlakukan pemerintah lokal bersifat fungsional terhadap ruang ekonomi lokal dengan cara mengefisienkan pelayanan pada masyarakat. Mereka menetapkan bahwa desentralisasi sekedar memfasilitasi efisiensi ekonomi-ekonomi lokal ini. Mereka sangat menyadari bahwa kebijakan-kebijakan desentralisasi tidak selalu mencapai tujuan untuk menjadikan pemerintah lokal lebih resposif dan bertanggungjawab, terutama karena lemahnya rancangan, korupsi dan pembajakan oleh elit (elite capture). Berdasarkan studi empiris komparatif, mereka berteori bahwa mendekatkan pemerintah pada warga negara serta memberikan kesempatan partisipasi warga negara dalam pengambilan keputusan niscaya akan menciptakan kondisi dimana desentralisasi akan mampu memenuhi janji-janjinya (Crook and Manor 200o; Manor 1999; World-Bank 2001).

\section{Argumen Hans Antlov}

Aliran pemikiran lain yang harus menjadi pertimbangan di seputar perdebatan mengenai

1 Carroll (2005) telah menganalisis secara mendalam Post-Washington Consensus yang memberi tempat besar bagi pembasisan teoriteori social capital lyang mendasari proyekproyek CDD, dan teori-teori rational choice yang mendasari kebijakan desentralisasi. 
desentralisasi di Indonesia dikemukakan oleh sekelompok sarjana peneliti maupun aktivis terpelajar yang bekerja pada sektor yang disebut sebagai "masyarakat sipil". Analisis yang paling berpengaruh ditulis oleh Hans Antlov. ${ }^{2}$ Antlov mengamati masalah utama di Indonesia bukan terletak pada tidak adanya pemerintah yang efektif (ia merujuk pada negara-negara Afrika dan Eropa Timur), bukan pula pemerintah kurang dekat dengan rakyat (ia merujuk pada Asia Timur). Sebaliknya, ia menegaskan bahwa di bawah Orde Baru, pemerintah terlalu dekat dengan rakyat dan terlalu efektif, mengintervensi seluruh aspek kehidupan publik dan pribadi. Tantangan masyarakat Indonesia adalah mereformasi lembaga-lembaga yang ada, bukan membuat institusi-institusi baru. Agendanya secara khusus adalah mendemokratiskan lembagalembaga negara sehingga rakyat bisa percaya mereka (Antlov 2004).

Ia mengibaratkan roti sandwich bahwa ada dua jenis kekuatan pembentuk pemerintahan lokal saat itu: proses desentralisasi dari pusat ke daerah (top-down) dan proses partisipasi warga negara dari masyarakat ke pusat (bottomup). Diharapkan proses ini akan "bertemu di pertengahan" dan mampu membentuk kontrak sosial baru serta membangun kepercayaaan pemerintah lokal yang vital bagi keberlangsungan Indonesia. Demokratisasi di tingkat nasional tidak akan bertahan lama tanpa memahami kebutuhan khusus masyarakat di tingkat lokal. Pertumbuhan ekonomi yang lebih berkelanjutan seiring dengan stabilitas politik hanya dapat terpenuhi melalui sebuah proses penguatan masyarakat dengan seksama

2 Ia adalah mantan Pimpinan Program Ford Foundation untuk tata pemerintahan dan masyarakat sipil, dan sekarang ia bekerja sebagai penasihat tata pemerintahan di USAID bagian program pendukung tata pemerintahan lokal di Indonesia. dan devolusi kekuasaan dari pusat ke tingkat lokal, dan sejumlah kewenangan, kebijakan, dan pengaturan dialihkan ke badan-badan lokal yang bertanggungjawab dan mampu mendekatkan jarak proses-proses kebijakan, pelaksanaan regulasi, penyelenggaraan program, dan layanan birokrasi kepada rakyat (Antlov 2004).

\section{Kritik Vedi Hadiz dan Toby Carroll}

Saya menempatkan karya-karya Vedi Hadiz yang menganut perspektif Structural Marxist dalam perbincangan dengan karyakarya kaum neo-institusionalis seperti direpresentasikan oleh Bank Dunia (Hadiz 2004a; Hadiz 2004b). Hadiz ${ }^{3}$ menempatkan konsekuensi desentralisasi sebagai pokok perdebatannya dengan "literatur-literatur neo-institusionalis", yang merupakan aliran pemikiran sejumlah besar orang dalam organisasi-organisasi pembangunan seperti Bank Dunia dan badan dana bantuan Amerika Serikat, USAID" (Hadiz 2004a: 698). ${ }^{4}$

3 Vedi Hadiz saat ini adalah professor di Asian Studies, Asia Institute, the University of Melbourne. Sebelumnya, dia mendapat $\mathrm{PhD}$ dari Murdock University, Australia, dibawah bimbingan langsung Richard Robinson.

4 Mohan dan Stokke (200o) menjuluki pandangan-pandangan neo-institutionalist ini sebagai 'revisionist neo-liberalism', yang pada pokoknya berposisi menganjurkan suatu strategi 'top-down' untuk reformasi kelembagaan dalam arti bahwa badan-badan pemerintahan dan NGO-NGO mengusahakan kelembagaan-kelembagaan yang ada lebih efisien dan mengikutkan kelompok-kelompok sasaran tertentu dalam proses pembangunan. Konseptualisasi partisipasi dan pemberdayaan model demikian ini didasarkan pada model tatanan kekuasaan yang seimbang. Kekuasaan melekat di dalam anggota-anggota individual suatu komunitas dan dapat meningkat seiring dengan keberhasilan dalam pencapaian tujuan-tujuan individual dan kolektif. Hal ini menunjukkan bahwa pemberdayaan dari kaum yang tak berdaya dapat dicapai melalui tatanan sosial yang ada tanpa akibat negatif apapun terhadap kekuasaan pihak yang berkuasa” (hlm. 249). 
Berbeda dengan pandangan kaum Neoinstitusionalist dan variannya dari eksponen 'masyarakat sipil', Hadiz menegaskan bahwa pengalaman kebijakan desentralisasi di Indonesia hanya sedikit mampu mencapai apa yang diyakini para pembaru tata pemerintahan. Yang nyatanya, desentralisasi itu telah berfungsi melayani perkembangan dari apa yang diistilahkannya dengan "newly decentralized, predatory networks of patronage" (Hadiz 2004a: 699). Dalam bahasa seharihari, mungkin maksud dari julukan ini adalah seperti yang diungkap dalam keluhan umum bahwa "bila dahulu kita berhadapan dengan satu Soeharto dengan kroninya, di masa desentralisasi ini Soeharto-nya dan kronikroninya ada dimana-mana." Dalam karyanya bersama dengan Richard Robinson, Hadiz juga dengan lugas mengkritik argumentasi Crok dan Manor (1998) dan Manor (2002), dengan menunjukkan bahwa institusiinstitusi demokrasi telah dipakai oleh banyak unsur rejim terdahulu yang tamak dan otoriter (Hadiz dan Robinson 2005; 2004). Hadiz dan Robinson menjabarkan bahwa anggota rejim otoriter dan oligarki sebelumnya telah berhasil membentuk kembali diri mereka layaknya aktor demokratik melalui partai-partai politik dan parlemen yang mereka pimpin. "Karena proses demokratisasi Indonesia telah dibajak oleh kepentingan mereka ... hasil-hasil dari desentralisasi tidak seperti yang diduga literatur-literatur neo-institutionalist" (Hadiz 2004a: 699). "Kaum Neo-institutionalist mengabaikan fakta bahwa demokratisasi, partisipasi publik, akuntabilitas serta hak-hak ekonomi dan sosial benar-benar terikat secara historis dengan hasil perjuangan kepentingankepentingan dan kekuatan-kekuatan sosial... hasil perubahan sosial yang berlangsung selama berabad-abad, seringkali diwarnai oleh konfrontasi kekerasan dan berdarah-darah, tidak kecuali pertarungan antara kelas-kelas sosial" (Hadiz 2004a: 702).

Berdasarkan penelitian lapangan di Sumatera Utara, Hadiz menyimpulkan bahwa ketimbang menghasilkan semacam technocratic 'good' governance seperti yang diidealkan oleh kaum neo-institutionalist, yang terjadi "justru meningkatkan bandit-banditdan preman politik dalam kepemimpinan partaipartai, parlemen-parlemen dan lembagalembaga eksekutif yang mengendalikan agenda desentralisasi”. Hadizmenyebut mereka sebagai "predator desentralisasi”. Sementara kaum neo-institutionalist cenderung menekankan aspek-aspek teknis desentralisasi, studi kasusnya itu menunjukkan bahwa pertarungan kekuasaan lebih berpengaruh pada bagaimana desentralisasi berkiprah daripada niat dan isi kebijakannya itu sendiri. Lebih dari itu, berbeda dengan kecenderungan para neoinstitutionalist yang menghubungkan prosesproses seperti desentralisasi, demokrasi, partisipasi, akuntabilitas dan peran masyarakat sipil/modal sosial, dalam kasus Indonesia jelas terlihat bahwa desentralisasi jelas-jelas direbut dan dikuasai oleh 'uncivil' groups (Hadiz 2004a: 716). Dan akhirnya, "sementara kaum Neo-institutionalist memimpikan, meskipun tidak diakuinya, desentralisasi sebagai bagian dari politik yang lebih luas dimana keahlian dan 'rasionalitas' teknokratik jalan menurut kehendaknya sendiri, dinamika politik yang nyata menunjukkan 'para ahli' teknokratik dan sekutu-sekutu mereka telah dilecehkan karena program-program mereka direbut oleh mereka yang lebih kukuh, terorganisir lebih baik dan tentu lebih berkuasa" (Hadiz 2004a: 717).

Pada butir terakhir ini, dengan menyadari sepenuhnya perbedaan mendasar di antara keduanya, penulis menemukan suatu konvergensi yang janggal antara argumen neoinstitutionalist dengan argumen structural marxist sekitar bahaya desentralisasi: keduanya mengakui bahwa sebagian besar bukti empiris 
memperlihatkan desentralisasi dimanfaatkan elit yang bermain dalam pengambilan keputusan publik yang tentunya menjadi arena pengaruh yang tidak setara antara kelompok yang diuntungkan dan kelompok yang dirugikan.

Karya Vedi Hadiz memiliki sejumlah konvergensi dengan karya-karya Toby Carroll (Carroll 2005; Carroll 2006), ${ }^{5}$ namun keduanya berbeda pendekatan dalam melihat Program Pengembangan Kecamatan (PPK) sebagai satu contoh evolusi dan reproduksi neoliberalisme yang secara umum mengarah pada hegemoni neoliberalisme. Carroll (2005) merangkum dasar teoritis yang disebut sebagai the PostWashington Consensus' Socio-Institutional Neoliberalism (PWC-SIN) dan menunjukkan bahwa "gagasan-gagasan teoritis di dalamnya sungguh memengaruhi bentuk tampilan programnya" (2005: 2). Ia dengan cerdik membuka simpul teoritiknya dan mengurai unsur-unsur debatnya dengan para ekonom makro Bank Dunia, dan kemudian secara kritis membongkar hubungan-hubungan yang tersembunyi di antara keduanya:

"apa yang menjadi terungkap dari analisis ini adalah bagaimana dekatnya Post-Washington Concensus (PWC) pada ekonomi neo-klasik, dan pada neoliberalisme bila dilihatnya sebagai proses politik yang berkembang. ... Dasar teoritis dari socio-institutional neo-liberalism sesungguhnya melayani neoliberalisme dengan 'suatu kehidupan baru' dan kesempatan baru untuk kembali terlibat (di bawah panduan-panduan teknokratis tentunya) dalam wilayah-wilayah yang sebelumnya tidak dapat mereka

5 Engels (2006) memiliki kesamaan penilaian terhadap KDP sebagai sebuah contoh baru versi neolieberal baru yang diadopsi Bank Dunia. Akan tetapi saya tidak mengkaji analisanya, karena Penilaiannya terhadap KDP sangat tipis. jangkau, misalnya tata pemerintahan dan kelembagaan sosial" (2005:3).

Selanjutnya, Carrol menggunakan karya Cammack $^{6}$ (Cammack 20o1b; Cammack 2002; Cammack 2003; Cammack 2004) untuk menegaskan bahwa "berpasangan dengan sumber ketidakadilan struktural dan struktur program yang dibiayai hutang, PPK dapat menjadi contoh yang gemilang ... dari meluaskan proletarisasi di dunianya orang miskin" (Carroll: 2). Memang, karya Cammack telah menawarkan analisis terbaru terhadap Bank Dunia dari perspektif Marxist tertentu, yang ingin ia sebut sebagai new materialist, dan mulai dengan penegasan bahwa Bank Dunia terus terlibat dalam "sebuah program sistematis untuk membentuk dan mengkonsolidasikan kapitalisme pada tataran global" (Cammack 2002: 127).

\section{E. Sumbangan Tania Li dan Frederich Rawski}

Dua kajian terbaru yang secara serius mempertimbangkan rasionalitas baru dari proyek-proyek Bank Dunia, dengan memeriksa KDP sebagai contoh luar biasa dimana Bank Dunia mendefinisikan ulang pendekatan neoliberalnya adalah karya Tania Li dan Frederich Rawski.

Tania Li menggunakan tafsir AngloFoucaultian dari Nicolas Rose tentang governmentality dan menggunakan konsep government through community, "memerintah melalui komunitas", untuk menunjukan betapa di tengah gilang-gemilang program pemberdayaan (empowerment) dan partisipasi, Bank Dunia telah berhasil menciptakan kondisi yang memungkinkan masyarakat

6 Saya akan kembali kepada perspektif Cammack untuk menjembatani perdebatan seputar desentralisasi dan $C D D$, dengan perdebatan di seputar akumulasi primitif. 
mengatur ulang aspirasi, keyakinan, perilaku, tindakan, dan hal-hal mental lainnya. Singkatnya, ia mengutip karya-karya David Scott tentang colonial governmentality (Scott 1995) bahwa kesemua itu "sedemikian rupa dibuat sehingga rakyat hanya mengikuti apa yang mereka yakini sebagai kepentingan mereka sendiri, dan akan melakukan apa yang mereka sendiri haruskan" (1995: 202). Scott menggunakan gagasan Foucault tentang governmentality dan berpendapat bahwa "untuk memahami proyek-proyek kekuasaan kolonial pada setiap peristiwa sejarah tertentu, seseorang harus memahami karakter dasar rasionalitas politik yang membentuknya. Dan apa yang dipentingkan bukanlah memahami bagaimana tindakan penjajah terhadap terjajah, bukan pula memahami bagaimana kolonialisme menyingkirkan dan merangkul penduduk asli sebagaimana mereka rancang. Melainkan mencoba mengungkap berbagai cara penggunaan kekuasaan kolonial, targettargetnya, dan berbagai bidang discursive dan non-discursive yang dicakupnya" (Scott 1995:204). Menurut penulis, karya Li itu mencoba mengungkap rasionalitas politik yang mampu menjadikan CDD itu sebagai suatu bentuk baru Proyek Pembangunan neoliberal.

Sejalan dengan karya Tania Li itu adalah karya Frederich Rawski (2005). Rawski mengakui bahwa CDD di Indonesia dan juga di Timor Timur membentuk apa yang ia sebut the community-based administrative regime (rejim administratif berbasis masyarakat) dan pengaruhnya dirasakan bukan hanya memberlakukan syarat-syarat prosedural, tapi juga melalui pembentukan dan penyebaran kerangka normatif yang menentukan ruang lingkup interaksi-interaksi masyarakat. "Untuk sebagian hal, mereka menyediakan kondisi bagi datangnya dana-dana pembangunan internasional dan keberhasilan cara prosedur administratif tertentu yang dimaksudkan untuk mengembangkan self-governance dan individual choice." Jadi Rawski menyimpulkan bahwa proyek-proyek CDD "bukan hanya bertujuan memaksimalkan efisiensi penyaluran dana internasional maupun menyokong lembaga-lembaga pemerintahan lokal, melainkan juga memengaruhi cara orang-orang berfikir mengenai hubungan sosial dalam komunitas mereka dan antar komunitas, negara maupun lembaga-lembaga internasional" (Rawski 2006:920). Dalamartikel tersebut, ia menunjukkan bagaimana struktur administratif PPK yang membuka persaingan antara kelompok-kelompok individu dalam proses penyampaian proposal proyek untuk perolehan dana "mencerminkan penekanan neoliberal terhadap enterpreneurship, inovasi individual, dan kompetisi pasar bebas.... norma-nilai demikian itu menyertakan prinsipprinsip, seperti akuntabilitas (dilaksanakan melalui aturan-aturan maupun prosedur yang mensyaratkan transparansi dalam pengambilan keputusan), dan hak partisipasi individu (yang dilaksanakan melalui aturan maupun prosedur seperti voting, sistem kuota, dan kewajiban konsultasi)" (Rawski 2006:942).

\section{F. Penemuan kembali "Akumulasi Primitif": Sumbangan Michael Perelman, Massimo de Angelis dan David Harvey}

Kebangkitan penggunaan kembali konsep analitik "akumulasi primitif" bisa dipahami melalui tiga inisiatif terkemuka:(1) sumbangsih pemikiran Michael Perelman, terutama dalam bukunya, The Invention of Capitalism, Classical Political Economy and Secret History of Primitive Accumulation (Perelman 2000), (2) sumbangsih pemikiran Massimo de Angelis (de Angelis 2001, 2004, 2007) serta debat pada Jurnal The Commoner dimana ia menjadi editor utama; dan (3) sumbangsih pemikiran 
David Harvey (Harvey 2003, 2004 2005; 2006c). Tiga pemikir ini berangkat dari semacam kesepakatan dari beberapa hal berikut:

a) Analisis Marx pada Capital vol 1, Bagian VIII yang membahas fenomena historis di Inggris selama periode transisi agraria menuju kapitalisme. Marx, mengutip karya Adam Smith mengenai previous accumulation dan menggunakannya untuk menganalisis proses pembentukan modal untuk pertama kalinya. Para sarjana umumnya mengutip kalimat Marx yang paling terkenal "akumulasi primitif berperan dalam ekonomi politik kira-kira sama seperti dosa asal pada teologi”; "tidak lain dari pada proses sejarah pemisahan produsen dari alat produksinya"; "ketika sejumlah besar orang tiba-tiba dipisahkan secara paksa dari caranya melanjutkan hidup, dan terlempar menjadi proletariat bebas dan 'bergantung melulu' pada pasar tenaga kerja”; "perampasan tanah dari para produser pertanian, dari para petani, adalah fondasi dari seluruh proses (pembentukan kapitalisme); "sebuah sejarah yang musti ditulis dalam almanak manusia dengan tinta darah dan api."

b) Yang disebut "akumulasi primitif" bukanlah fenomena sejarah yang hanya terjadi sekali saja, melainkan transformasi itu adalah proses yang berjalan terus menerus (on-going processes). Keberadaannya selalu menjadi ada dan penting dalam perkembangan kapitalisme. Maka, ada soal besar dalam teorisasinya mengapa kaum Marxist cenderung menafsirkan akumulasi primitif bukan sebagai fenomena yang berlangsung terusmenerus.

Michael Perelman bertanya mengapa Marx tidak lebih lugas mengemukakan sifat keberlangsungan akumulasi primitif? Ia menganggap bahwa cara Marx merumuskan akumulasi primitif sebagai kenyataan masa lampau sungguh dapat dimengerti, karena "Marx mengabdikan keterangannya mengenai akumulasi primitif sebagai kritik yang meyakinkan terhadap kapitalisme, yakni sekali kapitalisme memegang kendali, kaum kapitalis belajar bahwa tekanan-tekanan pasar sungguh lebih efektif dalam mengeksploitasi tenaga kerja ketimbang tindakan brutal akumulasi primitive" (Perelman 2000: 30). Perelman juga yang memecahkan misteri "primitif" dalam “akumulasi primitif". Seperti yang secara tegas tercantum dalam tulisan Marx, kata primitif berasal dari istilah Adam Smith: previous accumulation. Dalam karyanya, Perelman menunjukkan kalimat lengkap dimana Marx mengambil dari Adam Smith, yakni "the accumulation of stock must, in the nature of things, be previous to the division of labour". Marx yang menulis dalam bahasa Jerman menerjemahkan kata 'previous' dari karya Adam Smith menjadi "ursprunglich", dimana penerjemah bahasa Inggris Marx kemudian menerjemahkannya menjadi "primitive" (Perelman 2000: 25).

Sumbangsih yang lebih besar dari karya Perelman itu adalah secara lugas mengungkap hal yang ia sebut sebagai "siasat terselubung" (dark design) dari karya ekonom politik klasik seperti Adam Smith, David Ricardo, Sir James Stuart dan berbagai pemikiran lain yang kurang seterkenal mereka. Perelman menegaskan bahwa mereka:

“mengaburkan peran akumulasi primitif dalam karya teoritis mereka. Namun ... ketika kita merujuk pada surat, catatan harian, dan berbagai rekomendasi kebijakan mereka, arti penting akumulasi primitif menjadi jauh lebih jelas... Para penulis tersebut sepertinya dengan sengaja telah sejauh mungkin mengaburkan makna, supaya makna tersebut tidak melemahkan 
klaim-klaim keberlakukan teori mereka. Perjuangan masyarakat pedesaan untuk memenuhi kebutuhan hidup secara mandiri hanya lah menjadi bayang-bayang sekilas saja di seluruh karya ekonomi politik klasik dimana cara hidup yang ditampilkan secara sekilas itu telah dihapuskan sepenuhnya oleh proses akumulasi primitif. Akibatnya, proses ini benar-benar tidak diperhatikan oleh para pembaca modern karya klasik ekonomi politik" (Perelman 2000: 10-11).

Kemudian Perelman menyimpulkan “ekonomi politik klasik sungguh mengutamakan akumulasi primitif guna mempercepat pembangunan kapitalis, meski logika akumulasi primitif bertentangan sepenuhnya dengan apa yang dicanangkan oleh para ekonom politik klasik berupa nilainilai laissez-faire" (Perelman 2000: 12)

Sejalan dengan Perelman, Massimo de Angelis mendesak sebuah tafsir ulang gagasangagasan Marx tentang akumulasi primitif, yang dipahaminya tidak sekedar sebagai sebuah peristiwa masa lampau di awal perkembangan kapitalisme, tapi juga sebagai sebuah proses tak terpisahkan dengan berjalannya cara produksi kapitalis. Pendiriannya adalah:

a) pemisahan antara produser dan alat-alat produksi merupakan "suatu ciri umum akumulasi maupun akumulasi primitif" dan "berdasar intepretasi Marx ... tidak ada yang menunjukan bahwa pemisahan ini tidak terjadi setiap saat, bahkan dalam situasi cara produksi yang telah 'matang', ketika kondisi pemisahan ex novo telah berlangsung" (de Angelis 2000: 12);

b) "Perbedaan antara akumulasi dengan akumulasi primitif berdasarkan pada kondisi-kondisi berlangsungnya pemisahan tersebut", maka pada akumulasi primitif pemisahan itu berlangsung utamanya melalui kekuatan-kekuatan ekstraekonomi langsung oleh negara, kelompok kelas sosial tertentu, dan lain-lain (de Angelis 2000: 12).

De Angelis menyatakan bahwa dua butir yang dimaksudkan di atas mengungkit pertanyaan empiris untuk menyelidiki berbagai perbedaan bentuk dari akumulasi primitif. De Angelis memperluas argumentasi ini-dan lebih memilih menggunakan istilah lain yakni "enclosure"-dan menyajikan suatu taksonomi yang lengkap berbagai tipe dan model baru dari enclosure tersebut dalam kapitalisme global saat ini (De Angelis 2004). Dalam artikel tersebut, ia tidak hanya mencantumkan bentuk klasik enclosure tanah dan sumberdaya alam, akan tetapi juga beragam enclosure dalam ruang kota, kepemilikan bersama (social common), dan pengetahuan serta kehidupan.

Menurut deAngelis, modal harus dipahami sebagai sebuah kekuatan (force). Sehingga sehubungan dengan eclosure, modal harus dipahami sebagai enclosing social force (De Angelis 2004: 59, n. 5). Oleh sebab itu enclosure diartikan sebagai ciri yang melekat pada cara produksi kapitalisme karena modal cenderung mengkolonialisasi seluruh kehidupan, sementara itu rakyat yang bermukim di dunia tempat mereka hidup sesungguhnya mampu mengembangkan alternatif menghadapi komodifikasi hubungan-hubungan sosial. Ia mengelompokan enclosure menjadi dua model implementasi, yakni: (i) enclosure sebagai sebuah rancangan "kekuasaan atas" (power over), dan (ii) enclosure sebagai sebuah akibat dari proses akumulasi. Model yang pertama menunjukkan berbagai macam strategi yang sungguh-sungguh dirancang dengan berbagai bentuk dan nama (privatisasi, promosi ekspor, pengetatan anggaran dsb.). Sedangkan pada yang kedua, enclosure merupakan akibat yang tak direncanakan (unintended by-product) 
dari akumulasi yang (dalam bahasa ekonomi) dikenal sebagai "negative externalities", yang tak dikalkulasi dalam harga pasar dari barangbarang yang dihasilkan, karena biaya-biaya yang dikeluarkan oleh para penghasil barang itu memang berada di luar perusahaan yang memiliki barang itu (de Angelis 2004:77-78).

Jika modal dipahami sebagai sebuah enclosing social force, kekuatan sosial yang senantiasa melakukan enclosure, bagaimana de Angelis menteorisasi sesuatu "yang berada di luar modal itu"? Ia memikirkan pertanyaan itu secara serius, bukan sekedar pertanyaan analitis, tapi juga pertanyaan politis. Ia menegaskan posisinya bahwa

"apa yang berada di luar modal adalah suatu proses untuk menjadi yang lain, yang bukan modal, dan dengan demikian menghadirkan dirinya sebagai suatu halang-rintang terhadap proses akumulasi tanpa batas dan, sejak mula, proses enclosure, harus menghadapi ... berbagai bentuk perlawanan konkrit serta berbagai sikap manusia yang menyertainya. Dan jelaslah, bahwa, munculnya berbagai hal di luar modal ini tidak menjamin kepastian keberlangsungan dan reproduksi modal dengan sendirinya" (De Angelis 2007:229).

Kemudian, uraiannya sampai pada perbandingan dan kritik yang sungguh penting dan menarik terhadap cara bagaimana kaum Marxist menempatkan "hal-hal di luar modal dalam konteks kehadiran maupun ketidakhadirannya sebagai suatu fungsi dari sesuatu yang terbentuk secara ex-ante dan dalam hal ini akan sampai juga pada posisi akhirnya dalam proses perkembangan kapitalisme (Wolpe, Hart dan Negri), atau hal ini dalam proses menuju kematiannya melalui accumulation by dissposessions yang berlangsung terus (Harvey)" (de Angelis 2007:232). Ia melontarkan kritik pada sarjana-sarjana Marxian tersebut yang tidak memandang serius cara bagaimana hal-hal di luar modal itu dihasilkan secara terus menerus melalui perjuangan yang berkelanjutan. Ia mengenali adanya tiga dimensi penting dari perjuangan berkelanjutan ini: (a) watak komunitariannya; (b) proses artikulasinya; dan (c) pada sifat dan keefektifan tantangannya terhadap modal.

Tokoh lain yang mengerjakan kembali konsep akumulasi primitif ini adalah geografer ternama, David Harvey. Apa yang dikemukakan Harvey mengenai accumulation by disposession harus dilihat sebagai sebuah tema baru yang muncul dari upayanya selama hampir tiga dekade tanpa henti menunjukkan betapa pentingnya geography dalam analisa Marxian, yang kemudian usahanya ini dikenal dengan nama historical geographical materialism, suatu upaya sungguh-sungguh membawa ruang (space) sebagai kata kuncinya (Harvey 2006b). Usaha yang pada mulanya dirintis oleh Henry Lefebrve, seorang filsuf Marxian dari Perancis, yang dalam karya klasiknya The Production of Space (1974/1991) dengan brilian menunjukkan secara eksplisit mengusulkan suatu kosa kata "ruang" dan "produksi ruang" ke dalam ilmu-ilmu sosial dan humaniora.

Di sini kita akan mengedepankan sumbangsih pemikiran Harvey sebagai tafsir kontemporer atas akumulasi primitif, yang dia jabarkan berangkat dari elaborasinya mengenai capital overaccumulation dan tenaga kerja. Overaccumulation terjadi pada saat surplus modal (terlihat saat komoditaskomoditas berlimpah di pasar sehingga tidak dapat terjual tanpa rugi, saat kapasitas produktif ideal dan/atau ketika surplus modal uang kekurangan saluran untuk investasi produktif dan menguntungkan), dan surplus buruh (pengangguran meningkat) tidak lagi dapat diinvestasikan kembali pada tingkatan keuntungan rata-rata pada wilayah atau tempat 
asalnya. Menurut Harvey,

"surplus-surplus demikian bisa terserap melalui (a) pemindahan sementara investasi proyek-proyek modal atau pembiayaan sosial berjangka panjang (seperti pendidikan dan penelitian) yang pada gilirannya nilai modal itu akan masuk dalam sirkulasi modal di masa mendatang, (b) pengalihan ruang dengan membuka pasar baru, kapasitas produksi baru, dan kemungkinan-kemungkinan perolehan sumber daya, maupun tenaga kerja baru di lain tempat, atau (c) beberapa kombinasi dari butir (a) dan (b)" (Harvey 2003:106).

Selanjutnya,

"produksi ruang, organisasi pembagian kerja yang secara keseluruhannya baru dalam wilayah yag baru pula, pembukaan berbagai macam cara perolehan sumber daya baru yang jauh lebih murah, pembukaan wilayah-wilayah baru sebagai bagian dari dinamika ruang-ruang akumulasi modal, dan penetrasi terhadap formasi sosial yang ada oleh hubunganhubungan sosial kapitalis dan tatanan kelembagaannya (contohnya aturan kontrak dan kepemilikan pribadi) membuka jalan bagi penyerapan surplus modal maupun tenaga kerja. Namun, ekspansi re-organisasi dan rekontruksi geografis sering menjadi ancaman bagi nilai-nilai yang telah menancap dalam pada tempat-tempat itu (terikat secara sosial pada tanah), dan juga bagi nilai-nilai yang belum mewujud" (Harvey 2003: 116)

Accumulation by dispossession merupakan reformulasi Harvey atas "akumulasi primitif" setelah ia mengolah teori under-consumption dari Rosa Luxemberg dalam karyanya The Accumulation of Capital (1968). Menurutnya, banyak teori-teori Marxist mengenai akumulasi "mengabaikan proses akumulasi yang terbentuk melalui berbagai macam tindakan perampasan, penipuan, dan kekerasan yang diperlakukan atas berbagai hal di "keadaan awal" yang dianggap tidak lagi relevan atau - di sini ia kemudian merujuk pada Rosa Luxemberg - yang diperlakukan terhadap yang berada "di luar dari" kapitalisme yang berlaku bagaikan suatu sistem tertutup. Selanjutnya, "mengevaluasi kembali peran yang menetap dan terus berkelanjutan dari praktek-praktek buas dari "akumulasi primitif" atau "akumulasi awal-mula” dalam sebuah geografi sejarah akumulasi modal, sungguh merupakan "tugas yang mendesak sebagaimana akhirakhir ini disampaikan oleh para komentator". Harvey merujuk pada Parelman (200o), de Angelis (2000) dan perdebatan besar-besaran dalam The Commoner. Menurutnya "apa yang dilakukan melalui accumulation by disposession adalah melepaskan serangkaian aset (termasuk tenaga kerja) dengan biaya yang sangat rendah (dan dalam banyak hal sungguh tanpa biaya). Modal yang telah terakumulasi berlebihan dapat dipakai untuk merampas rangkaian aset tersebut dan segera dapat membawanya ke dalam suatu penggunaan yang menguntungkannya" (Harvey 2003: 149)

Harvey memutuskan untuk meluaskan dan menamakannya accumulation by disposession (akumulasi dengan cara perampasan), karena ia merasa "adalah janggal untuk menyebut suatu proses yang berkelanjutan dari 'akumulasi primitif' atau 'akumulasi awal-mula”' (Harvey 2003:144). Dalam karyanya, "Comment in Commentaries" (Harvey 2006a), yang ditulisnya sebagai tanggapan atas sejumlah komentar serta kritik atas New Imperialism (Ashman dan Calinicos 2006; Brenner 2006; Brenner 2006; Castree 2006; Fine 2006; Suteliffe 2006; Wood 2006), ia berkeras bahwa "praktek-praktek kanibalistik dan predatoris yang terjadi terus di negara-negara kapitalis maju dengan kedok privatisasi, reformasi 
pasar, pengetatan anggaran kesejahteraan dan neoliberalisasi lebih cocok bila ditampilkan sebagai accumulation by disposession. Accumulation by disposession secara kualititaf dan teoritis berbeda dengan apa yang terjadi di masa awal kapitalisme." (Harvey 2006a: 158)

Pada The New Imperialism, ia menampilkan beragam contoh kontemporer baik di negara maju maupun negara berkembang yang disebutnya sebagai the cutting edge of accumulation by dispossession, yaitu: "asetaset yang dipegang oleh negara atau dikelola secara bersama oleh penduduk dilepas ke pasar ketika masa modal-modal yang berkelebihan itu sanggup berinvestasi, memperbaharui dan berspekulasi dengan menggunakan aset-aset tersebut”. Dalam A Brief History of Neoliberalism, ia memerinci akumulasi lewat perampasan itu menjadi:

a) Privatisasi dan komodifikasi,

b) Finansialisasi,

c) Pengelolaan dan manipulasian krisis, dan

d) Redistribusi aset negara (Harvey 2005: 157158)

\section{G. Proyek Pembangunan dalam Pembangunan Kapitalisme}

Karya-karya Paul Cammack (2001a; 2002; 2003; 2004) menegaskan keharusan memahami peran kontemporer Bank Dunia yang telah dan terus terlibat dalam "serangkaian programprogram sistematis dalam pembentukan dan konsolidasi kapitalisme di tingkat global" (Cammack 2002:127). Penegasannya yang lebih spesifik adalah "Bank Dunia telah menjalankan misi baru untuk dirinya selama beberapa dekade terakhir... untuk menyelesaikan proses akumulasi primitif di tingkat global (Cammack 20o1b:198).

Menurut Cammack, secara umum Bank Dunia membutuhkan terciptanya pasar tenaga kerja, penyelenggaraan hak kekayaan intelektual, mengatur kelembagaan agar pasar dapat tempat semestinya, layanan infrastruktur, pendidikan dan kesehatan yang diperlukan agar ekonomi pasar bekerja dan sebagainya. Semua ini menggambarkan sebuah proyek perluasan dan konsolidasi kapitalisme di negara berkembang. Yang lebih spesifik, "sumber daya Bank Dunia dipakai untuk memperdalam kebijakan-kebijakan pemerintah yang melancarkan proletarisasi, memudahkan eksploitasi dan meningkatkan ketergantungan pasar" (Cammack 20o1b: 198). Cammack menegaskan bahwa alasan mendasar strategi ini adalah kebutuhan untuk menciptakan 'cadangan tenaga kerja' (reserved army of labour) dalam skala global, dimana:

"kapitalisme yang matang itu membutuhkan dan terus membentuk 'penduduk yang menganggur' yang tanpanya proses pendisiplinan kapitalisme tidak akan bekerja; kehadiran 'cadangan tenaga kerja industrial' itu akan mempertahankan upah yang rendah, dan cenderung membuat tenaga kerja hanya hidup sekedar hidup; dan mereka yang menganggur berada dalam kondisi miskin absolut. Singkatnya, untuk menghapuskan kemiskinan harus menghapuskan sistem kapitalisme itu sendiri” (Cammack 2001b: 195).

Upaya melancarkan proses proletarisasi dilakukan oleh Bank Dunia dengan bekerja pada "cadangan tenaga kerja" tersebut melalui upaya-upaya memelihara disiplin pasar, membatasi meningkatnya upah mereka dalam pasar, dan memelihara tingkat keuntungan yang diinginkannya.

"Kapitalisme membutuhkan orangorang yang dipersiapkan untuk menjadi para pekerja potensial, di wilayah-wilayah dimana pendisiplinan tersebut belum berlangsung ... Dalam masa di akhir abad dua puluh dan awal abad duapuluh satu, Bank Dunia 
memikul tanggungjawab untuk mengerangkakan dan menguatkan kebijakan-kebijakan yang diperlukan untuk sedemikian rupa membuat disiplin-disiplin itu terwujud" (Cammack 2001b:195).

Dengan merujuk pada karya Cammack tersebut, dapatkah kita langsung menarik kesimpulan deduktif bahwa Bank Dunia yang mendukung CDD dan desentralisasi Indonesia adalah bagian dari desain besar untuk menciptakan kondisi untuk "cadangan tenaga kerja”? Atau, dapatkah kita menegaskan bahwa intervensi Bank Dunia telah dan terusmenerus berorentasi untuk membentuk dunia 'di luar modal' dalam rangka pendisiplinan rakyat yang pada gilirannya akan memasuki putaran modal, dan memperbesar kontrol pasar terhadap mereka? Bisakah kita menggariskan gerakan-gerakan sosial dewasa ini sebagai bagian perjuangan melawan accumulation by disposession seperti diramal Harvey bahwa accumulation by disposession akan langsung mendorong terciptanya gerakan sosial melawan kecenderungan yang akan memusuhi kapitalisme? Dapatkah kita mempertegas bahwa-menggunakan kerangka pikir de Angelis-gerakan-gerakan sosial yang ada sekarang ini merupakan bagian dari memperjuangkan kepentingan bersama yang akan membawa masyarakat ke rute perjalanan yang berbeda dari kapitalisme, dan membangun halang-rintang yang permanen bagi proses enclosure selanjutnya? Pertanyaan serupa bisa diajukan untuk mendorong kita berpikir secara serius tentang bagaimana memanfaatkan perdebatan teoritis yang telah dirangkum sebelumnya.

Dalam karya tulis ini, penulis telah mengkaji ulang berbagai pemikiran mengenai pembangunan dalam konteks pembangunan kapitalisme. Ketimbang membuat suatu operasi-operasi logika deduktif, akan jauh lebih tepat dan berguna apabila berorientasi untuk menghasilkan konsep-konsep yang konkrit untuk menghadapi realitas konkrit yang berbeda di berbagai tempat dan berubah dari waktu-ke-waktu (concrete in history), seperti yang diusulkan Stuart Hall dalam mediskusikan metode kerja Marx (Hall 2003). Sebelum kesana, penulis akan mengkaji ulang perdebatan teoritis antara David Harvey, Massimo de Angelis dan Gillian Hart tentang beberapa aspek terkait dengan pokok bahasan penulis mengenai gerakan sosial, yakni mengenai kekuatan "di luar modal" dan perjuangan melawan accumulation by disposession.

Harvey menegaskan, "kapitalisme membutuhkan dan selalu menciptakan kekuatan di luar modal ini”. Gagasan "kekuatan di luar modal" ini sangat lah relevan. Akan tetapi kapitalisme dapat juga memanfaatkan kekuatan di luar modal ini, baik formasi sosial non-kapitalis maupun atau beberapa sektor dalam kapitalisme-seperti pendidikanyang belum sepenuhnya terproletarisasi, atau kapitalisme juga dapat menciptakannya secara aktif (Harvey 2003:141). Namun, berbeda dengan Harvey, de Angelis merujuk kepada Hart (2002; 2005) dan lainnya bahwa "tidak ada jaminan bahwa setelah 'tenaga kerja dilepaskan' dari ikatan-ikatan nonkapitalisnya maka mereka akan mendapatkan pekerjaan dan ikut proses reproduksi sirkut kapitalis". Berarti bahwa proses enclosure selalu menyertakan krisis reproduksi sosial dan berbagai bentuk perjuangan di seputar reproduksi sosial tersebut (De Angelis 2007: 232).

Lebih jauh lagi, de Angelis memandang teorisasi Harvey mengenai "kekuatan di luar modal" dalam konteks accumulation by disposession memiliki kelemahan, karena Harvey menempatkannya semata-mata sebagai sebuah objek akumulasi dan disposession 
dipandang melulu sebagai suatu cara dari akumulasi modal. De Angelis menunjukkan kekuatan dan sekaligus kelemahan dari cara bagaimana "kekuatan di luar modal" itu diteorisasi. De Angelis mengusulkan untuk menambal lubang teoritis itu dan mencoba memahami kekuatan di luar modal sebagai sebuah ruang (space) ${ }^{7}$ yang merupakan "suatu kondisi material yang dimiliki bersama ... dimana problema reproduksi sosial itu sungguh-sungguh bergantung pada kaum yang tersingkir, baik yang telah dapat pekerjaan maupun belum, dan tentunya daya jangkau organisasi mereka" (Huruf miring berasal dari kutipan asli) (De Angelis 2007: 232). Dengan kata lain, reproduksi sosial kekuatan di luar modal itu benar-benar bergantung pada efektivitas, jangkauan organisasional dan cara bagaimana kelompok-kelompok masyarakat itu memperjuangkan dan membentuk ruang yang dimiliki bersama tersebut.

Problematisasi "ruang di luar modal" dan bagaimana perjuangan-perjuangan untuk memproduksi, mengisinya dan mengubahnya yang dilakukan, hampir tidak mucul dalam kerangka pikiran Harvey. Pada perspektif Harvey, accumulation by dispossession dapat diramalkan secara otomatis memicu bangkitnya gerakan sosial penentang pelaku dispossession itu. Selanjutnya, ketika gerakan sosial telah menguat dan tampil sebagai suatu hambatan tersendiri bagi modal, berbagai mesin kelembagaan kapitalis akan melangkah untuk membongkar halang-rintang itu. Mesinmesin kapitalis pun mendesak pemerintah

7 De Angelis menggunakan istilah detritus yang dipinjamnya dari Chari (2005), dan kemudian mendefinisikannya sebagai "the layers of waste inscribed in the body and in the environment and that emerge out of articulation of life practices following their own conatus to capital's loops (and their conatus)" (De Angelis 2007: 232). Suatu penjelasan ilustratif mengenai conatus-detritus terdapat pada karya de Angelis (2007: 234-237). untuk menggunakan kekuasaannya demi menciptakan sebuah syarat-syarat yang kondusif bagi proses enclosure selanjutnya. Namun, wawasan makro Harvey mengabaikan bagaimana proses-proses kongkrit yang menghubungkan keduanya. Hart berpendapat bahwagerakan-gerakan perlawanan tidakdapat ditebak secara otomatis dari accumulation by dispossession (Hart 2006). Selain itu, "fakta-fakta material yang menghubungkan dispossession itu dengan gerakan perlawanan perlu dianalisis apa maknanya, yang benarbenar memperhitungkan beragam cara determinasi, hubungan dan artikulasi historis/ geografisnya" (Hart 2006: 11)

\section{H. Refleksi Penutup}

Penulis mengajukan argumen pokok mengenai pentingnya kepekaan dan pemahaman mengenai pertarungan dan perundingan baru dan bagaimana ruang-ruang itu diproduksi di berbagai lokalitas, khususnya yang terbentuk sebagai konsekuensi dari kebijakan desentralisasi, proyek-proyek CDD dan pembangunan kapitalisme yang berjalan secara tidak sama antara satu lokasi dengan lokasilainnya. Visibilitasdari hal ini bergantung pada posisi dan cara pandang masing-masing. Dalam konteks ini perlu ditegaskan terlebih dahulu bahwa cara pandang kita benar-benar akan dipengaruhi koordinat dan tempat dimana kita berangkat dan kemana kita akan pergi. Pentingnya posisi dan kesadaran akan posisi (positionality) ini akan memengaruhi isi dan cara pengetahuan dihasilkan dan disajikan. Hal ini telah disadari lama oleh sejumlah penulis kalangan antropologi refleksif, sosiologi ilmu, dan feminis di tengah tahun 1980-an (misalnya Clifford dan Marcus 1986; Haraway 1988; Hartsock 1987). Argumen utama yang mereka kemukakan adalah bahwa semua pengetahuan akademik, juga pengetahuan lainnya, senantiasa bergantung situasi (are 
always situated), dan selalu dihasilkan oleh pelaku yang berposisi tertentu (are always produced by positioned actors), yang bekerja di dalam berbagai hubungan sosial dan di antara berbagai posisi lain yang dihadapinya. Semua inilah yang membuat satu pengetahuan yang satu berbeda dengan pengetahuan lainnya, sebagai akibat dari proses pembuatannya (dilakukan oleh siapa, bagaimana dan juga untuk siapa bentuk akhir pengetahuan itu mau disajikan) (Cook 2005).

Penulis yakin bahwa justru dengan kesadaran dan pengakuan bahwa pengetahuan yang dihasilkan senantiasa bersifat kontekstual dan relasional inilah yang akan dinilai lebih jujur, meyakinkan dan memberdayakan para pembaca dan peneliti lainnya untuk melihat hubungan-hubungan baru yang sering tidak terduga, termasukyang memberi kemungkinan untuk aksi-aksi kolektif yang baru pula. Penegasan ini sangatlah penting untuk diperhadapkan dengan klaim bahwa proses produksi dan narasi ilmu sosial dan humaniora itu bebas-posisi alias netral. Dalam hal ini yang musti diselidiki adalah bukan benar salahnya klaim tersebut, karena akan sia-sia dan tak berkesudahan, melainkan dalam kondisi apa dan bagaimana klaim itu disebarluaskan dan kemudian dianut oleh komunitas tertentu, dan kemudian kepentingan apa yang diemban oleh pengetahuan dan penyebar-penganut klaim tersebut.

Dalamartikelinipenulismenawarkansuatu pendekatan yang dapat dijadikan pegangan untuk penelitian empiris mengenali produksi ruang-ruang politik baru di tingkat lokal, yang terbentuk sebagai akibat dari pengaruh antara:

(a) proses-proses kebijakan desentralisasi;

(b) proyek-proyek CDD; dan (c) proyekproyek organisasi-organisasi non-pemerintah, dan cara bagaimana ketiganya berinteraksi menyusun ulang karakter pemerintahan lokal. Penulis melihat bagaimana gejala kelompok- kelompok rakyat yang tidak lagi punya rasa hormat atau takut lagi pada instruksi-instruksi yang otoritarian, merupakan ruang yang disi oleh proyek-proyek CDD dan proyek-proyek organisasi non-pemerintah, yang pada intinya adalah suatu cara memerintah kelompokkelompok masyarakat melalui masyarakat yang mengatur dirinya sendiri. Studi-studi mengenai governmentality, seperti yang dibuat oleh Tania Li (2005), berada dalam pendekatan ini.

Arus utama skenario neo-institutionalist untuk membentuk tata kepemerintahan yang baik, good governance, antar badan pemerintah, antara pemerintah dengan kelompok masyarakat, dan antar kelompok masyarakat itu mungkin hanya sedikit yang berjalan seperti yang dirancang, dan tak disangka-sangka, ternyata telah dibajak oleh elite-elite dalam jaringan oligarki kapitalis cum politico-birokrat otoritarian lama yang mampu bekerja dalam alam demokrasiseperti dikemukakan oleh Vedi Hadiz (2004a; 2004b). Aliansi elit kapitalis dan politicobirokrat itu ternyata sanggup terus bercokol dan menjalankan kuasanya yang bersifat predatoris melintasi batas-batas hidup dari tatanan politik otoritarian di masa lampau. Mereka sanggup dan pada gilirannya menyenangi menjadi pemain utama dalam tatanan politik demokratis di masa kini. Pada titik ini pula, penulis dapat melihat apa yang diargumentasikan ole Cammack (20o1a; 2002; 2003; 2004) bahwa proyek-proyek pembangunan Bank Dunia pun berperan membentuk "kekuatan di luar modal", mendisiplinkan mereka, dan pada gilirannya menjadi sumber dari cadangan tenaga kerja (reserve army of labor) yang lebih siap mengisi pos-pos pekerjaan yang dibutuhkan secara spesifik sebagai konsekuensi dari perkembangan kapitalisme agraria dan industri yang lebih luas. 
Akan tetapi, penulis berpendapat bahwa seluruh argumentasi tersebut tidak secara eksplisit mengungkap bagaimana kesemua itu bukanlahsepenuhnyaberuparuang-ruangyang telah dikuasai sebelumnya dan sepenuhnya oleh kekuatan modal. Sesungguhnya ruangruang itu adalah ruang-ruang pertarungan dan perundingan (spaces of contestation and negotiation), yang pada dasarnya bersifat relatif terbuka dapat juga dibentuk oleh mereka yang dapat memasukinya. Penulis melihat proses kebijakan desentralisasi sesungguhnya juga membuka ruang bagi pertarungan dan perundingan beragam visi, agenda, dan skenario, dimana berbagai kemungkinan baru dapat terwujud bergantung pada sejauh mana hubungan-hubunganantarkekuatan-kekuatan sosial yang bekerja pada ruang itu tersebut dapat ditempa, dipertemukan dan disinergikan untuk perjuangan sosial yang transformatif. Seperti yang dicontohkan pada tulisan kami yang sebelumnya (Fauzi dan Zakaria 2001, 2002, Zakaria et al 2001), kebijakan desentralisasi ternyata memberikan ruang bagi kelompokkelompok gerakan petani dan masyarakat adat untuk memberdayakan dan menampilkan diri untuk mengusung kepentingannya serta mengintervensi pembentukan kebijakan lokal di tingkat kabupaten serta desa-desa di Kabupaten Garut (Jawa Barat), Kabupaten Toraja (Sulawesi Tengah), dan Kabupaten Sanggau (Kalimantan Barat). Yang dapat mereka hasilkan adalah suatu pengakuan atas pentingnya agenda untuk mempertahankan atau merebut kembali akses pada wilayah yang disebut "tanah/hutan negara" yang dikuasai perusahaan perkebunan dan badan usaha kehutanan. Akses itu dipertahankan atau diperoleh kembali melalui penggarapan tanah secara langsung, pengubahan tata guna tanah dan pengelolaan sumberdaya agraria dan lingkungan setempat.
Dengan pedekatan ini penulis melihat bahwaproyek-proyekCDDjugamemungkinkan komunitas untuk mereorganisasi diri bukan untuk ke arah yang dirancang oleh kaum neoinstitutionalist, bukan pula sekedar menerima menjadi korban aliansi dari elite-elite kapitalis cum politico-birokrat yang predatoris itu, atau menyiapkan diri sendiri menjadi tenaga kerja yang telah terdisiplinkan. Akan tetapi proyekproyek tersebut juga membuka ruang baru bagi kerja pengorganisasian komunitas untuk agenda-agenda gerakan sosial yang luas. ${ }^{8}$

Namun perlu disadari sepenuhnya bahwa memasuki ruang-ruang demikian itu memiliki konsekuensi untuk berhadapan dengan berbagai agenda dari kekuatan lain yang tidak dengan sendiri sejalan dengan maksud pengorganisasian komunitas itu sendiri, dan dengan demikian tidak akan ada jaminan bahwa pertarungan dan perundingan tersebut akan dengan sendirinya bersifat transformatif terhadap hubungan kekuasaan yang melingkupinya. Agenda

8 Seperti yang telah ditunjukkan oleh sekelompok aktivis perempuan yang secara cemerlang telah berhasil mengerjakan kembali skema CDD menjadi ruang yang dipergunakan untuk pemberdayaan bagi para perempuan kepala keluarga, yang menjanda karena proses-proses perang, konflik etnis, maupun migrasi. Dengan mengerjakan kembali proyek-proyek CDD, mereka dimungkinkan untuk memperjuangkan pengakuan atas status, identitas dan martabatnya menjadi Perempuan Kepala Keluarga (PEKKA). Lebih dari itu, mereka telah sanggup menunjukkan kemampuan untuk mengatur diri sendiri dan mengelola proyek-proyek secara lebih baik dari pada yang dikelola kelompokkelompok pengelola CDD lainnya (lihat http://www.pekka.or.id/). PEKKA berhasil membuat perempuan-perempuan kepala keluarga bisa memperoleh akses pada administrasi kependudukan (akte kelahiran, dil) dan kemudahan pengurusan perceraian di pengadilan (lihat Akhmadi dkk 2010). Inovasi lainnya adalah "Sistem Pemantauan Kesejahteraan Keluarga Berbasis Komunitas (SPKBK-PEKKA)" (lihat PEKKA, 2014; Zuminarni 2009). 
dari kekuatan lainnya dapat merupakan suatu bentuk kooptasi untuk menaklukkan, atau melembutkan tuntutan transformasi sosial dari komunitas yang terorganisir, atau justru saling menguatkan. Jadi, interaksi dengan berbagai macam kekuatan sosial lainnya memungkinan mengubah atau justru menguatkan cita-cita dan rute transformasi sosial yang mereka tempuh. Sehingga yang diperlukan adalah suatu perjuangan terusmenerus untuk melakukan apa yang Antonio Gramsci (1971:238-239) maksudkan dengan war of position.

Masalah terbesar bagi kalangan akademik dan para aktivis terdidik Indonesia saat ini adalah kesulitan untuk mendapatkan dan menggunakan alat konseptual yang memadai untuk mengenali, menganalisa dan memahami bagaimana pembangunan kapitalisme yang secara geografis dan historis tidak sama antara satu lokasi dengan lokasi lainnya bagaimana pembangunan kapitalisme itu berhubungan dengan peran dari negara, dan konsekuensinya pada diferensiasi kelas sosial dan pembagian kerja laki-perempuan di berbagai tingkatan mulai dari skala keluarga hingga unit-unit produksi komoditas di pedesaan maupun perkotaan. Juga, lebih jauh dari itu, menghubungkannya dengan reproduksi kebudayaan (cultural reproduction) dan reproduksi sosial (social reproduction) dari kapitalisme itu, serta produksi kebudayaan (cultural production) secara lebih luas (mengenai perbedaan ketiganya lihat Willis 1981).

Adalah sungguh penting untuk menghubungkan kesemua itu dengan ruang-ruang yang terbentuk dalam proyekproyek Pembangunan, baik yang dijalankan pemerintah maupun oleh lembaga swadaya masyarakat, dan juga dengan apa yang dilakukan kelompok-kelompok gerakan sosial. Hanya dengan pemahaman dan analisis yang memadai inilah, maka dapat diperoleh pemahaman mengenai "batas-batas struktural" dan "kemungkinan-kemungkinan konjungtural” (Jessop 1982:253) dari suatu jenis aksi kolektif baru dalam rangka transformasi sosial. Sering kali kita menemukan klaim-klaim naif dari proyek-proyek Pembangunan itu, yang sesungguhnya tanpa sadar ikut dibentuk bagian dari arus utama yang bersesuaian dan melancarkan atau setidaknya bersifat adaptif terhadap pembangunan kapitalisme tersebut. Sebaliknya, mereka yang sanggup mengenali secara konkrit hubungannya dengan formasi sosial kapitalisme yang lebih luas tentunya akan mudah melihat bagaimana ruang-ruang perundingan dan pertarungan itu terjadi, dan mungkin dapat memproduksi, mengisi atau mengubah ruang-ruang itu. Bagi kalangan gerakan sosial khususnya, penulis yakin, hal ini akan membuat mereka dapat lebih baik dalam melakukanupaya penyadaran (concientization) dan pemberdayaan (empowerment) kelompokkelompok komuntas marjinal, atau mereka yang potensial maupun nyatanya mendukung kelompok-kelompok masyarakat marginal itu.

Akhirnya, adalah merupakan salah satu tantangan bagi para ahli pemikir yang mengembangkan analisis kritis (critical scholars) untuk mengikuti dan menganalisis secara spesifik pergerakan menyempit dan meluasnya ruang-ruang pertarungan dan perundingan itu, rute perjalanan berbagai kekuatan sosial, dan cara bagaimana berbagai kekuatan-kekuatan itu bekerja dalam ruang-ruang itu dari waktu ke waktu, serta menghubungkan kesemuanya itu dengan aktualisasi pembangunan kapitalis yang secara geografis dan historis berbeda antara satu wilayah dengan wilayah lainnya.

\section{Ucapan Terima Kasih}

Naskah tidak mungkin dibuat tanpa kuliah-kuliah maupun konsultasi individual sekitar tahun 2007-2009 dengan Prof. 
Gillian Hart dari Departement of Geography, University of California, Berkeley. Selain itu, naskah ini pernah diedarkan secara terbatas dan memperoleh apresiasi, kritik dan komentar dari Nancy Peluso, Bonnie Setiawan, Mohamad Shohibudin, Laksmi Savitri, Coen Husain Pontoh, dan Vedi Hadiz. Kepada mereka diucapkan terima kasih, dan hal yang sama kepada Lilis Mulyani yang telah membuat review atas naskah ini. Seperti biasanya, tanggungjawab naskah ini sepenuhnya berada pada penulis.

\section{Daftar Pustaka}

Akhmadi, Asri Yusrina, Sri Budiyati, dan Athia Yumna. 2010. "Access to Justice: Empowering Female Heads of Household in Indonesia. Case Studies in Nanggroe Aceh Darussalam, West Java, West Kalimantan, and East Nusa Tenggara” Jakarta: Lembaga Penelitian SMERU, 2010. http://www.smeru. or.id/sites/default/files/publication/ accesstojustice.pdf (akses terakhir 27 April 2018).

Antlov, Hans. 2004. "The Making of Democratic Local Governance in Indonesia." in Democracy, Globalization and Decentralization in Southeast Asia, edited by F. L. K. Wah, and Joakim Öjendal. Copenhagen: NIAS Press.

Ashman, Sam and Alex Callinicos. 2006. "Capital Accumulation and the State System: Assessing david Harvey's The New Imperialism." Historical Materialism 14:107-131.

Aspinall, Edward. 2004. "Indonesia: Civil Society and Democratic Breakthrough." Pp. 61-96 in Civil Society and Political Change in Asia: Expanding and Contracting Democratic Space, edited by M. Alagappa. Stanford: Stanford University Press.
Brenner, Robert. 2006. "What Is and What Is Not, Imperialism?” Historical materialism 14:79-105.

Cammack, Paul. 20o1a. "Making Poverty Work." in Socialist register 2002: A World of Contradictions, edited by L. Panitch and C. Leys. London: Merlin Press.

-. 2001b. "Making the Poor Work for Globalization." New Political Economy 6:397-408.

—. 2002. "Attacking The Poor." New Left Review 13:125-134.

-.2003. "The Governance of Global Capitalism: A New Materialist Perspective." Historical Materialism 11:37-59.

—. 2004. "What the World Bank Means by Poverty Reduction, and Why It Matters." New Political Economy 9:189-211.

Caroll, Toby. 2006. “The World Bank's Socioinstitutional Neoliberalism: A Case Study from Indonesia." in The Workshop on the World Bank, Lee Kwan Yew School of Public Policy, National University of Singapore. Singapore.

Carroll, Toby. 2005. "Efficiency of What and for Whom? The Theoretical Underpinnings of the Post-Washington Concensus' Socio-Institutional Neoliberalism." in Working Paper No. 122. Perth: Murdoch University.

—. 2006. “The World Bank's Socio-institutional Neoliberalism: A Case Study from Indonesia." in The Workshop on the World Bank, Lee Kwan Yew School of Public Policy, National University of Singapore. Singapore.

Castree, Noer. 2006. "David Harvey's Symptomatic Silence.” Historical materialism 14:35-57.

Clifford, James, and George Marcus (eds), 1986, Writing Culture: The Poetics and Politics of Ethnography, Los Angeles \& 
Berkeley: University of California Press.

Cook, 2005, "Positionality/Situated Knowledge", dalam D. Atkinson et.al. (eds.), Cultural Geography: A Critical Dictionary of Key Concepts halaman 1626, London: I.B. Tauris.

Craigh, David and Doug Porter. 2006. Development Beyond Neoliberalism? Governance, Poverty Reduction and Political Economy. London: Routledge.

Cribb, Robert. 1990. "The Indonesian Killings 1965-1966." Clayton: Centre for Southeast Asian Studies, Monash University.

-. 2001. "Genocide in Indonesia 1965-1966." Journal of Genocide Research 3:219-239.

Crook, Richard and James Manor. 2000. Democratic Decentralization. OECD Working Paper Series. Washington, DC.: The World Bank.

DeAngelis, Massimo. 2001. "Marxand Primitive Accumulation: The Continuous Character of Capital's 'Enclosures." The Commoner 2 (September) (available at www.thecommoner.org).

-. 2004. "Separating the Doing and the Deed: Capital and the Continuous Character of Enclosures." Historical Materialism 12:57-87.

- 2007. The Begining of History. Vaule Struggles and Global Capital. London: Pluto Press.

Engel, Susan. 2006. "Where to Neoliberalism? The World Bank and the Post-National Washington Consensus in Indonesia and Vietnem." in the 16th Biennial Conference of the Asian Studies Association of Australia. Wollongong, 26 - 29 June 2006.

Fauzi, Noer dan R. Yando Zakaria 2001, Mensiasati Otonomi Daerah, Panduan Fasilitasi Pengakuan dan Pemulihan Hak-hak Rakyat, Yogyakarta: Insist
Press bekerjasama dengan Konsorsium Pembaruan Agraria.

_. 2002 "Democratizing Decentralization: Local Initiatives from Indonesia”. Paper submitted for the International Association for the Study of Common Property $9^{\text {th }}$ Biennial Conference, Zimbabwe, 2002. http:// dlc.dlib.indiana.edu/documents/ diro/oo/oo/o8/18/dlc-ooooo818-01/ fauzin170502.pdf .

Farid, Hilmar. 2005a. “Indonesia’s Original Sin: Mass Killings and Capitalist Expansion, 1965-66." Inter-Asia Cultural Studies 6:3-16.

- (2005b) The class question in Indonesian social sciences. V. R. Hadiz and D. Dhakidae (editors) Social science and power in Indonesia (pp. 167-195) Jakarta: Equinox Pub. And Singapore: Institute of Southeast Asian Studies.

Fine, Ben. 2006. "Debating the 'New' Imperialism." Historical Materialism 14:133-156.

Foucault, Michael. 1994. On the genealogy of ethics. In P. Rabinow (Ed.), Ethics, subjectivity and truth, Essential works of Foucault 1954-1984, Volume I (pp. 253-280). New York: The New Press.

Goldman, Michael. 2005a. Imperial Nature: The World Bank and Strugle for Social Justice in the Age of Globalization. New Haven, CT: Yale Uniersity Press.

-. 2005b. "Tracing the Roots/Routes of World Bank Power." International Journal of Sociology and Social Policy 25:10-29.

Gramsci, Antonio. 1971. Selections form the Prision Notebook, edited and translated by Quintin Hoare \& Goffrey Nowell Smith, Lawrence and Wishart, London.

Griffin, Penny. 2006. “The World Bank.” New Political Economy 11:571-581. 
Guggenheim, Scott, Tatag Wiranto, Yogana Prasta, and Susan Wong. 2004. "Indonesia's Kecamatan Development Program: A Large-Scale Use of Community Development to Reduce Poverty." in Scaling Up Poverty Reduction: A Global Learning Processes and Conference. Shanghai.

Hadiz, R. Vedi and Richard Robison. 2005. "Neo-liberal Reforms and Illiberal Consolidations: The Indonesia Paradox." teh journal of Development Studies 41:220-241.

Hadiz, Vedi. 2004a. "Decentralisation and Democracy in Indonesia: A Critique of Neo-Institutionalist Perpectives." Development and Change 35:697-718.

-. 2004b. "Indonesian Local Party Politics: A Site of Resistance to Neo-Liberal Reform." Critical Asian Studies 36:615636.

Hall, Stuart. 2003. "Marx's Notes on Method: A "Reading" Of the "1857 Introduction"."

Haraway, Donna, 1988, “Situated Knowledges: The Science Question in Feminism and Privilege of Partial Perspective", dalam Feminist Studies 14, p.575-99.

Hartsock, Nancy, 1987, “The Feminist Standpoint" dalam Sandra Harding (ed.), Feminism and Methodology, Milton Keynes: Open University Press.

Hart, Gillian. 2001: Development Debates in the 1990s: Culs de sac and Promising Paths. Progress in Human Geography 25, 605-14.

_.2006. "Denaturalizing Dispossession: Critical Ethnography in the Age of Resurgent Imperialism." Antipode 38:977-1004.

Harvey, David. 2003. The New Imperialism. Oxford: Oxford University Press.
-.2004."The'New' Imperialism:Accumulation by Disposession." in Socialist Register 2004, edited by L. Panitch and C. Leys. New York: Monthly Review Press.

-. 2005. A Brief History of Neoliberalism. Oxford: Oxford University Press.

-. 2006a. "Comment on Commentaries." Historical Materialism 14:157-166.

- 2006b. Space of Global Capitalism: Toward a Theory of Uneven Geographical Development. London: Verso.

-. 2006c. Spaces of Global Capitalism. London: Verso.

Hofman, Bert and Kai Kaiser. 2002. "The Making of the Big Bang and its Aftermath, A Political Economy Perspective." Paper presented at the conference "Can Decentralization Help Rebuild Indonesia?" The International Studies Program, Andrew Young School of Policy Studies, Georgia State University, Atlanta. http://wwwl.worldbank. org/publicsector/LearningProgram/ Decentralization/Hofman2.pdf Last accesed on 07/08/2009.

Jessop, Bob. 1982. The Capitalist State. New York: New York University Press.

Lefebvre, Hendry. 1974/1991. The Production of Space. D. Nicholson-Smith (translator), Oxford: Basil Blackwell.

Li, Tania. 2006. "Neoliberal Strategies of Government Through Community: The Social Development Program of the World Bank in Indonesia." in International Law and Justice Working Papers. New York: Institute for International Law and Justice, New York University School of Law.

Manor, James. 1999. The Political Economy of Democratic Decentralization. Washington, DC.: The World Bank.

Mansuri, Ghazala and Vijayendra Rao. 2004. "Community-Based and -Driven 
Development: A Critical Review." The World Bank Research Obserer 19:1-39.

Menko Kesra 2008. Pedoman Umum PNPM Mandiri. Jakarta: Kementerian Kordinator Kesejahteraan Rakyat.

Mohan, Giles and Stokke, Kristian. 200o.. Participatory development and empowerment: the dangers of localism. Third World Quarterly, 21(2):247-268.

Pender, John. 2001. "From 'Structural Adjustment' to 'Comprehensive Development Framework': Conditionality Transformed?" Third World Quarterly 22:397-411.

PEKKA. (2014). "Menguak Keberadaan dan Kehidupan Perempuan Kepala Keluarga”. Laporan Hasil Sistem Pemantauan Kesejahteraan Berbasis Komunitas (SPKBK-PEKKA). Jakarta: Lembaga Penelitian SMERU.

https://www.pekka.or.id/documents/Buku-1. pdf (akses terahir pada 27 April 2018)

https://www.pekka.or.id/documents/Bukuz. pdf (akses terahir pada 27 April 2018)

Perelman, Michael. 20oo. The Invention of Capitalism: Classical Political Economy and the Secret History of Primitive Accumulation. Durham: Duke University Press.

Rawski, Frederick. 2005. "World Bank Community-Driven Development Programming in Indonesia and East Timor: Implications for the Study of Administrative Law." New York University Journal of International Law and Politics 37:919-951.

Robison, Richard and Vedi R. Hadiz. 2004. Reorganizing Power in Indonesia: The Politics of Oligarchy in an Age of Markets. London: Routledge.

Scott, David. 1995. "Colonial Governmentality." Social Text 43:161-220.
Stiglitz, Joseph E. 2002. "Participation and Development: Perspective from Comprehensive Development Paradigm." Review of Development Economics 6:163-182.

Sutcliffe, Bob. 2006. "Imperialisme Old and New: A Comment on David Harvey's The New Imperialism and Ellen Meiksins Wood's Empire of Capital." Historical Materialism 14:59-78.

Tim Kordinasi PNPM Mandiri. 2014. Paket Informasi PNPM Mandiri 2014. Jakarta: Tim Kordinasi PNPM Mandiri.

Willis, Paul. 1981. "Cultural Production is Different from Cultural Reproduction is Different from Social Reproduction is Different from Reproduction." Interchange, 12(2-3): 48 -67

Wong, Susan and Scott Guggenheim. 2005. "Community-Driven Development: Decentralization's Accountability Challenge." Pp. 253-267 in East Asia Decentralizes: Making Local Government Work, edited by T. W. Bank. Washington: The World Bank.

Wood, Ellen Meiksins. 2006. "Logics of Power: A Converation with David Harvey." Historical Materialism 14:9-34.

World-Bank. 2001. "Promoting Good Governance with Social Funds and Decentralization.” PREM Notes Public Sector 51.

Zulminarni, Nani. 2009. 'Change through Empowerment-The Journey of Indonesia Women Heads of Households.' Project report presented at the PEKKA Workshop, held by the World Bank in Hotel Borobudur, Jakarta, June 2009. 